\title{
The visible and less-visible world: Social Ethnography in the study of World
}

\section{Christianity}

\begin{abstract}
Exploring the idea of religion as the cumulative experiences of an individual within a community, part of lived human existence, this article will argue that 'World Christianity' needs to be understood as a social phenomenon deeply enmeshed in the emotional and intellectual encounters of humanity within which the 'sacred' is located and experienced. Christian belief and its corresponding symbols are intimately linked to the worldly conditions and 'lived-in-environments'. Drawing from ethnographic fieldwork in South India, Ghana and England, this article will explore the place of sacred objects, images of the divine, and rituals, which are often treated with great reverence so as to extract power and to prevent misfortune in personal, social, and economic life. From a social ethnographic perspective, this article will shed light on the methodological challenges stemming from the fact that human beings are not neutral/passive observers but are rather active participants in shaping their notions of the 'sacred'.
\end{abstract}

Key words: Social Ethnography, Christianity, Lived Faith, Material Religion, Spiritual Agency, Worldview and Positionality 
Ethnography requires us to dive deep into the sea of other people's lives and find a way to swim with them. It requires commitment, endurance, constant improvisation, humility, sociality, and the ability to give oneself up to and for others. It also entails the ability to retrieve oneself and be prepared to rethink, from this position, every- thing one thinks one knows. And then it needs one to swim back to the shore and be prepared that this shore is almost always going to be different from the shore where one began. ${ }^{1}$

Concurring with Alpa Shah, the primary concern of this article is an invitation to consider social ethnography as a critical research tool in the study of World Christianity. As an emerging academic field, World Christianity ought not to be seen merely as an extension of European and Colonial missionary Christianity. By framing the central epistemological discussion around the 'visible and less-visible' frame, this article examines the relationship between people's lives and their notions of 'sacred' within Christianity. By 'visible world' I mean a tangible world and 'less-visible world' means, not necessarily tangible but part of the sensory perception and knowledge, which deeply impacts the tangible world. Exploring the idea of religion as the cumulative experiences of an individual within a community, part of lived human existence, I argue that Christianity as a religion is a lived social phenomenon deeply enmeshed in the emotional and intellectual encounters of humanity within which the 'sacred' is located and experienced. Christian belief and its corresponding symbols are intimately linked to the worldly conditions and 'lived-in-environments'.

The thought world of Christians is not separate from the everyday 'profane' world, but it is affected, influenced, and transformed by experiences in the 'commonsense' world. ${ }^{2}$ Moving on from the Colonial utilisation of anthropology in early missionary work, current social ethnographic research offers crucial framework to understand material religious life within 
global Christianity. ${ }^{3}$ Religious symbols, objects and ritual performances make things that are not visible into the visible, transforms 'transcendent' into the 'immanent', facilitates 'spiritual' into 'physical', accessible to human contact. The central contention that Christianity is a social phenomenon that needs to be studied and interpreted within particular social and embodied contexts may seem to be a banal truism. But the significant point of departure within the emerging field of World Christianity is that a socio-ethnographic view resists perception that considers Christianity in the global majority world as merely an extension of European or missionary Christianity. Paying attention to the lived dimension offers theologians a fresh understanding of how Christianity is embraced and lived in diverse and often in disparate context. This article makes a case that theology from the global majority world would be strengthened by grounding in socio-ethnographic existential methodologies. Because it captures proactively the thought-worlds of individuals and communities in their lived context.

\section{The visible and the less visible: A case for Reflexive Social Ethnography}

The sociological reflexive ethnographic approach ${ }^{4}$ stresses the importance of people being the subjects as well as the objects of any analysis. ${ }^{5}$ My methodological research outlook also stems from my subjective experience as a Dalit Christian and do not simply mirror reflections of a universal social world of Christians. Hence, there is an element of subjectivity involved in this research as in my life, which is unavoidable in social ethnographic research. The causal relationship between the researcher and the researched ${ }^{6}$ often enables one to transcend and transform the ethnographer's subjective ideas. ${ }^{7}$ Thus, the central reflection of this article is a result of engaging with my personal experience as a Dalit Christian and with the experience of living among diverse Christians in south India, Ghana and Britain in order to have a grounded knowledge of the context being observed and studied. ${ }^{8}$ It is incumbent upon researchers to 
honestly and intelligently capture people's stories and the context in which they are conceived in order to understand the larger social thought-world in which they live. ${ }^{9}$ In other words, the environment impacts sense-impressions. A great deal of our knowledge is embodied knowledge, grounded in our bodily responses, and the self is realised in relation to its environment. Hence, existential positionality is a critical theological factor.

Johanna Vento suggests that "Religions are complex, living sets of practices that change throughout time, that are named and interpreted from a variety of perspectives, and that have varied local forms in any given space and time." ${ }^{10}$ Within such a framework the idea of religion as the cumulative experience of an individual within a community is crucial, because as Geertz says, "it is not in solitude that faith is made." ${ }^{11}$ Anthropologically, Christianity as a religion is part of lived human existence, having a profoundly human dimension, which arises from and addresses intellectual, emotional and social sources, in which the less visible is enmeshed in the visible. ${ }^{12}$ In this context we should seriously consider abandoning any pursuit of a dualistic study of Christianity. Instead we should study the intertwined and complex process of religious experience in human communities. ${ }^{13}$ There is a need to explore how human beings learn and conceptualise in "the relational context of (their) practical engagement within the lived-inenvironments." 14 Theoretically, Bourdieu proposes that such an understanding is a process of "internalisation of externality." 15 Hence, it is almost impossible to understand the beliefs and practices of Christians across the world in abstraction from the context in which they are conceived and lived. ${ }^{16}$ Simply put, our knowledge as human beings is mediated and conditioned by our relationships with others and the environment in which they are located. ${ }^{17}$ With the aforementioned theoretical basis let me outline three observations from South India, Ghana and England. 


\section{1. 'Sacred' objects and images in South India}

The Holy Bible: A Source of the Sacred

The Bible is often considered to be a Parisutha, a holy book, and is treated with great reverence within the predominately illiterate Dalit Christian communities in South India. ${ }^{18}$ It is also popularly believed to contain enormous powers within it, which can be used for personal as well as communal benefits. During one of my fieldworks among Anglican Dalit Christians in Tamil Nadu, Chandra, an elderly lady in one of the Christian communities, and wife of a church elder, disclosed her belief in the miraculous power Yesusami (Jesus) made possible through the Bible, which she believes contains 'His' power. One evening, I saw Chandra visibly upset, walking up to the church and praying with her Bible in hand. Afterwards she returned home and entered her backyard. I was surprised to see Chandra place the Bible on the heads of some of her sheep and pray for healing. Upon enquiring she explained that she was praying for her sick sheep, which were affected by a contagious disease. After a few of them had died, she decided to use the power that she saw latent in the Bible to protect the sheep. She firmly believed that the Bible had the power to heal if she placed it upon the sheep while praying to Yesusami. Chandra also added that if the sheep die, her only source of livelihood would be gone. She recollected that from her previous experiences when she and her husband would visit sick people, they would pray with the Bible by placing it upon the ill person who would frequently be healed. For Chandra, the Bible contains Yesusami's healing power within itself and it is released when she prays to Yesusami with faith and good intention. Chandra also confided that she often keeps the Bible under her pillow while going to sleep to avoid bad dreams and keeping evil spirits from reaching or harming her. Chandra admitted to this practice for more than five decades and claims to always find it to be beneficial. 
Chandra is not alone in this type of practice as several other women and men from the Dalit Christian communities share this belief in the power of the Bible. Many in the community use the Bible for various reasons apart from reading and learning scripture, even if they are unable to read. In some houses it is kept in an elevated place along with portraits of Yesusami and sometimes even with other deities, decorations and candles, almost performing a semipoojai (worship) to it. The Bible as a sacred object almost becomes a mystical tool used to prevent misfortune in personal, social, and economic life. Chandra infuses new meaning into the use and role of the Bible in her life primarily through her faith and past experience. But this process does not stop there as it permeates into other aspects of her life as well. Within the religiously rich symbolic thought world of South India, it can be observed that Christian sacred objects, like the cross and the bible, can take on new roles other than what they were intended for, with new meaning ascribed by the users. In the case of the Dalit Christian communities grounded in religio-cultural life of South India, this process effectively gives a new meaning to the Christian sacred objects. The Bible in this context not only contains 'spiritual text' but 'spiritual power' as well, making it a source of sacred itself.

\section{Portraits of Yesusami and Mary Matha}

Yesusami and Mary Matha (Mother Mary) are the predominant portraits present in most households of the Dalit Christians in South India. Interestingly, in one of the villages there is not a single portrait of either figure within the church building because the local church leader believes that Christians should not worship idols (i.e. portraits), which is also the official stance of the local church. Contrary to this view, many of the Christians in the community worship and venerate pictures of Yesusami and Mary Matha privately within their homes. Peter, a young member of the Christian community, explained that he spends five minutes every morning in front of Yesusami's portrait before leaving for work. He believes that this 'prayerful act' provides him safety, strength, and peace every day. 
In another instance, Nathan, the local guardian of the church and a respected member of the community, decided to farm rabbits with the help of a loan arranged by his employer. Prior to receiving the baby rabbits, he prepared a shed for the rabbit cages, inside of which he hung a portrait of Yesusami. When asked why, Nathan replied that by placing the picture of Yesusami with the rabbits he ensures their protection and well being, making sure that his business venture would be prosperous. He further added that the portrait of Yesusami is equivalent to the real presence of Yesusami among the rabbits, and promises good safety and better profit.

This practice is widely prevalent among most Dalit Christians in South India. Yacobu, who works in the poultry farm, keeps a portrait of Yesusami in his tent while working. He believes that this picture helps him work well and consequently to earn a good reputation from his landlord. Rani, an elderly widow in the Christian community who maintains the church premises for free, also offers a good insight into the way images of the divine are perceived in the community. She has portraits of Yesusami, the Mary Matha, and a deceased former bishop hung on a wall of her house. These portraits occupy a special place in her wall and are adorned with decorations, much like the Hindu shrines. One day she had food items placed in front of the portraits and when I asked, she explained that she continues to make the same dishes the bishop liked when he used to visit the village and now that he is dead, she offers it to his portrait. Her gesture of hospitality was extended to the portraits of Yesusami and the Mary Matha next to the deceased bishop, hoping that they would consume it, and in return bless her. In the past she claimed to see the foods disappear. ${ }^{19}$

The visual and physical interaction with the Bible and portraits of the divine and the hopeful extraction of power among Dalit Christians, provides useful insights into the relationship between divine images and devotees. Moreover, these images have practical implications in the lives of Dalit Christians. As David Morgan's intervention on the usage of 
divine images in the Indian subcontinent shows, the devotees and viewers of divine portraits and images enter into a relationship, a 'covenant' with the image and use it to interpret sociospiritual empowerment. ${ }^{20}$ Moreover these observations highlight the material expression of belief and the sensory experience of religious faith. ${ }^{21}$ As explained earlier, the Dalit Christian community amply demonstrates that images and portraits of the divine assume a real presence through their psychosocial interpretations producing functional value in their lives.

\section{Expressions of belief and faith in Ghana}

With over 70 percent of the population identifying as Christian, Ghana is an important country in West Africa ${ }^{22}$ for the study of World Christianity. Ghanaian Christians are drawn from various ethnic groupings such as Akan, Ewe and Guan, to name a few. Christianity is also represented by various denominations such as Anglicanism, Presbyterianism, Methodism and Catholicism. Significantly, Ghana has also seen a noteworthy growth of the Pentecostal movement both through independent churches and within traditional Christian denominations. ${ }^{23}$ One of the key features of Christianity in Ghana is that it is significantly influenced by traditional belief system and spiritual practices. Much of the Christian religious practices are embedded within the traditional belief system. From my ethnographic fieldwork and conversations with Christians in Ghana, ${ }^{24}$ it is possible to trace the influence of Akan or Ashanti mythology in their Christian beliefs. The epistemological aspects of traditional belief systems are that the invisible world of divine beings is intrinsically connected with the visible, phenomenal world. Hence both aspects, the visible and less visible worlds, have significant impact on the mundane lives of human beings. In order to harness the potential benefit of divine beings in the mundane lives, human beings seek in many ways to draw their presence wherever 
they live and work, not just in 'sacred' places, such as churches or temples. Christians in Ghana are not an exception to this worldview.

\section{Shop Names}

What began as comical observations of shop names ended up in a serious research into why and how people name their shops for special purposes. Here are few shop names to explain this point further with the interpretation and meaning given by some of the Christian shop owners:

- Jesus is the Bread of Life Grocery. It is an obvious connection to the metaphor of Jesus as the bread of life, as this message instantly connects to the people who know it, thus making business better.

- Nothing but Prayer Electrical Company. In a context of constant shortage of electricity and frequent electricity failures, Immanuel, the shop owner, chose to name his shop emphasising the power of prayer.

- Jesus Loves Fashion. Dressing up for various occasions is a central cultural feature in Ghana. According to Jemima, the shop owner, adding Jesus to that combination legitimises it and sends the message that Jesus is not against fashion.

Besides, there are other fascinating shop names like Divine Connection Phone Shop, God's Finger Fitting Shop, God's Miracle Drinking Spot, Dry Bones Shall Live Again Haircut, Consuming Fire Fast Foods and Hotel Messiah: A Glimpse of Heaven. During my fieldwork, it became apparent that the Christian proprietors of these shops had specific reasons to name their shops with the earlier mentioned titles. The responses ranged from a very clear faith standpoint to strategic naming to attract people of particular faith interest. Nevertheless, the names were given for a reason in the first place; it was not random. During the fieldwork conversations, it became evident that people within the Christian context were using their faith 
and religious belonging to gain a foothold in the material marketplace. Similarly, in Muslim majority areas like Kumasi region, one would be able find 'Allah' inserted in their shop names. Ghanaian society being an overwhelmingly religious society, the usage of faith, be it Christian, Muslim, or inspired by traditional religions' related, to name entrepreneurial establishments, not only gives them some legitimacy but also works favourably for the business among the local population.

\section{Slaying the Devil}

My field work also included research among three megachurches in Accra, namely, Action Chapel International, Lighthouse Chapel International, and International Central Gospel Church, each with unique leadership and congregational following. ${ }^{25}$ For the purpose of this article, I offer one observation that captures the importance of social ethnography as a methodological tool. I attended one of the Wednesday prayer meetings at Action Chapel International. The worshipers were invited to slay the devil and stamp on him. It was a highly charged evening. But what made the evening a special one was the moment when Archbishop Duncan (the lead pastor) appeared on stage to lead the congregation in fervent prayer, climaxing in picking up a solid metal sword to slay the devil. After this spiritual warfare performance, he invited the congregation to trample on the slained devil. The loud music blasting from the speakers along with the commands from the pastor to stamp on the slain devil created an ambience of spiritual warfare within the chapel building. After an hour-long highly charged prayer service, I was able to have a conversation with few of the worshipers present in that service. The personal stories from those Christians offered an account of astounding sensory spiritual gathering. They were questioned, what did slaying the devil service mean to them? Among several responses, one particular answer captured the essence of that evening. Victor, one of the respondents, said, 'in that single act of slaying the devil, the archbishop has defeated the devil and, in the process, set us free.' In other words, the less visible devil to 
normal human eyes has been slayed by the archbishop in the visible act of wielding the sword. The act of wielding the sword and slaying the devil makes the less visible reality a tangible event that transforms the life of the believer and gives them freedom.

The Christian shop names and the slaying the devil comport well within the epistemological and religious worldview of traditional Ghanaian religious culture and society. In a society that is deeply shaped by traditional religious values and thought-world, Christianity and its social manifestations seamlessly flow into the life and textures of the people. Therefore, an apparent Christian message in shop name or the emotionally charged theatrics of an archbishop in slaying the devil does not look out of place; rather it finds meaning and relevance in the existential thought world of Ghanaian Christians. Their perceptions of belief and faith are to be situated and comprehended within the epistemological aspects of traditional Ghanaian belief systems, that the invisible world of divine beings is intrinsically connected with the visible, phenomenal world. Without the critical reflexive ethnographic enquiry many would have missed the popular interpretations of such mundane daily occurrences among Christians in Ghana.

\section{Baptisms in Burnley}

While researching the nature of interfaith relations between Christians and Muslims in the North of England, I was struck by an interesting observation in Burnley. ${ }^{26}$ Burnley was a prominent mill city in the early part of twentieth century, but since then it has declined due to economic and industrial changes. With a history of race riots ${ }^{27}$ and social fragmentation, there is a growing tension between different communities. In this context, baptisms ${ }^{28}$ has taken a new meaning and purpose. Burnley has one of the largest Muslim populations in the North of England; significantly Asian, particularly from Pakistan and Bangladesh. Needless to say, 
many parts of the city are segregated between white British and south Asian Muslim communities. As in any English town, Burnley has several Anglican churches doted around the city, and often follow the geographical civic parish system. As part of my research, one particular Anglican church was observed, which recorded a significant increase in baptisms in its parish neighbourhood. Incidentally, the street where the church is located also became an artificial boundary between the Muslim neighbourhood and the predominantly white neighbourhood.

In England, as per the parish system, the residents of a particular parish are entitled to have baptisms, as a traditional Anglican rite of passage, even if they are not regular churchgoers. In this particular Anglican parish, given its background, not many of them were regular churchgoers. However, in the past few years, there has been a steady increase in the number of people from the parish requesting for baptisms and christenings. The parish church often conducts these baptisms/christenings as a stand-alone service on Sundays, after the main worship service. In effect, many of the baptisms and the people who participate in them do not mingle or come into contact with the actual worshiping community. Often these baptisms are an elaborate celebration culminating with a big party in the local pub or restaurant. Most of the participants dress up as if they are going to a wedding party. These occasions are public demonstration of their social belonging. When I enquired about the intentions for doing baptisms, many responded by saying that it is through them that they are able to ascertain their Christian identity over against the Muslim identity. Through baptism/christening many of the worshipers were also able to distinguish their racial identities, between 'white' British and 'brown’ British Asians. Further enquiry made it apparent that area baptisms are primarily functioning as social identity markers rather than religious rites of passage.

Not only baptisms have assumed a new purpose, but this particular process also brings out the racialization of Christian religious identities. Especially in the context of Christians and 
Muslims living in a fragmented society with a history of racial tensions. Put simply, to be a white British means to be a Christian and to be a brown person means to be a south Asian Muslim. Without proper contextualisation of this lived reality and all the underlying religious and racial tensions, one might entirely miss the assumptions that shape the relationship between Christians and Muslims with different racial and ethnic background. Further, it is important to observe how traditional Christian ritual practices are contextualised by the practitioners. Such a meticulous attention will serve to properly unpack the way these rituals are being utilised in different communities for various socio-cultural practices, other than their primary-intended purposes.

\section{The Social Cosmology of World Christianity: An Ethnographic Approach.}

The article employs three very diverse case studies to make its case: Christianity in south India, Ghana, and Britain. Although they have varied epistemological starting points, beyond the Platonic/Cartesian dualism, these lived experiences offer a non-binary approach to Christian faith in their local context. Further, the common thread of contextual conceptualisation of the less visible world and its impact on the visible world is clearly evident in the preceding observations of various Christian communities. Such awareness stems from an approach that takes account of its social setting within which notions of 'sacred' are conceived for the individual and collective. In all three contextual observations the 'social eye' functions as an important tool in comprehending their religious views. Human determination and situatedness takes precedence. The divine is conceived within that human situatedness. Such a view leads to underlining the relationships between the divine and the human. From the observations discussed earlier it is clear that it is possible to develop an understanding of causal and reciprocal relationship between the visible and the less visible world. Individuals and community members in these Christian communities were able to establish a reciprocal communication with the divine while demanding certain specific responses from God. 
Essentially, as suggested by Merleau-Ponty, thoughts and actions belonging to the religious realm are very much conceived and couched within the social environment of individuals and communities. ${ }^{29}$ However, all three different case studies are instructive of the fact that ambiguity and open-endedness are not exceptions but the rule of life within a context of bounded notions of religious identity.

There were also insights into the perception of the material and spiritual worlds and the mutual impact they have upon each other. The spiritual worldview among Christians is that they have located their understanding of God, Jesus, and Holy Spirit within their inherited traditional local worldview as well as their existential context. Another important aspect to stem from this reflexive social ethnographic approach is that Christians observed in this study do not distinguish between this world and the spiritual world, but rather see no clear divisions between the two. Nobody knows where the material world ends and the spiritual world begins. They rather believe that whatever happens, it happens in this world, a non dualistic approach to the universe, thus making religious experience decentralised and unmediated within their context. Theologically, this approach could be called lived theology. ${ }^{30}$ Most of the Christian communities that I researched and discussed here consider themselves to be part of the environment and the forces of nature, which essentially sustains their life. Their worldview is interwoven within their surrounding context. Due to such a perception, there is an obvious dilemma among some Christians to reconcile with a pietistic European Christian worldview that denies this visible world.

Fieldwork among Christians in India, Ghana and England shows that there is a desire among them to extract hope through these processes, which gives them meaning and purpose in life. Given the indeterminate nature of their situatedness, hope is a popular theological motif among the Christian communities discussed here. Hirokazu Miyazaki, through extensive anthropological work, suggests that hope as a sociological and community construct enables 
people to willingly embrace uncertainty and offers a concrete method for keeping knowledge moving in conditions of uncertainty. ${ }^{31}$ Anthropologically, hope is considered the very ground of existence and being. Hope is the frame of reference through which one makes sense of the world and hope is not simply a wishful thinking. Hope is also characterized by absence of cynicism. Hope gives life, purpose, and meaning. In this regard, hope is a vital life force. Without hope, a person could be considered empty. In other words, hope is essentially communal in nature, thrives in relationships, which ties in with their identities. Hope and faith are intertwined, which assumes primacy in a particular situation is down to the individual. Expansively, in many societies that I studied individuals do not have fenced off identities. They rather draw their identity from being part of a collective communal identity. In that situation, the community nurtures hope. Scarcity of hope generates fear, anger and hatred, which can collapse a community. Breakdown of relationships and fragmentation of communities shatters collective and inclusive identities, opening up space for despair. Despair in turn engenders human tendency to look inward and develop an exclusive mindset searching back to lost glory. However, hope as described earlier stretches beyond such narrow presumptions and offers the possibility for human beings to re-imagine their existence. In all three contexts, the Dalit Christians in India, Ghanaian Christian Shop owners and 'white' Christians in Burnley are all not only drawing their identity from their relationship to the sacred but, in the process, they also infuse their life with hope. The contention of this article is that by utilizing socioethnographic lens, we are able to appreciate the deeper meaning of their lives. After a nuanced analysis, Boopalan makes the following observation,

By allowing us to recognize the diverse ways in which people exercise their agency in relation to religion, ethnography infuses Christian (and other) theological thinking with a dose of humility. It does this by showing the limitations of metacategories and metanarratives. Given dominant tendencies toward subscribing to metanarratives in 
Christian (and other) theological thinking, ethnography_ by revealing fault lines within such metanarratives - could save Christian (and other) theology from hegemony, contributing to making the world a safe place for human difference and thereby even saving the world. ${ }^{32}$

Principally, the diverse ethnographic observations suggest that the knowledge of the less visible evolves from the situatedness of an individual or community, rather than being externally imposed. This sheds light on the fact that human beings are not neutral observers but are rather active participants in shaping their notions of the less visible. The religious world is not separate from the everyday 'profane' world, but it is affected, influenced, and transformed by experiences in the 'commonsense' world. ${ }^{33}$ This approach to the study of World Christianity is instructive, since it shows that it is impossible to collapse all that happens into an incomprehensible whole. Rather, we need to observe the inter-wovenness of the whole. Christianity cannot be considered as merely an abstract engagement in doctrine or dogma, nor a routine recitation of creeds and mantras. Likewise, Christianity cannot be regarded as something one does with speech or reason alone, but with the body and the spaces we inhabit. Careful analysis of the social cosmology of World Christianity implies that the interface between the visible and less visible aspects of the world is a fluid, dynamic and constantly creative space, where the individual and the collective realise their interconnectedness, to one another and to God.

\section{CONCLUSION}

As argued earlier, the Christian experience captured in the case studies from India, Ghana and England cannot be understood outside of their locatedness and the environment they inhabit. It also raises a crucial question of studying Christianity as an exclusive religion as it tends to downplay the complexity of mundane human context. Traditionally, studies of Christianity often tend to privilege what people 'believe in' over what they 'practice', hence missing the 
significance of the dynamic interaction between belief and practice. My argument is that given that human beings are not neutral/passive observers, but are rather active participants in shaping their notions of the visible and less visible world, we should seriously consider how we go about studying or researching World Christianity. Within the emerging field of World Christianity, I would argue that social ethnographic methodology should play a critical part in the effort to capture the complexity of lived Christian experience and develop a comprehensive understanding of it by teasing out the tacit knowledge that informs Christian belief and worldview. The three cases examined in this article reinforce the notion that ambiguity and open-endedness are not exceptions but the rule of life within a context of bounded notions of religious identity. This article argues, therefore, for fundamental the need for world Christianity scholars to pay close attention to the fluidity, multiplicity, and ambiguity of particular Christian experiences. ${ }^{34}$ The religious thought-world is not separate from the everyday 'profane' world. On the contrary, it is affected, influenced, and transformed by experiences in the 'commonsense' world. Social ethnographic research methodology could play a crucial role in understanding that material religious symbols and objects turn things that are not as visible into the visible, transforms the 'transcendent' into the 'immanent', the 'spiritual' into the 'physical', enabling us to capture the relationship between people's lives and their notions of 'sacred' within Christianity.

Anderson H M Jeremiah is an Anglican theologian and lecturer in World Christianity at Lancaster University, UK. He is the author of Community and Worldview (2013) and numerous book chapters and articles that explores the lived facet of Christian faith. He can be contacted at this email: a.jeremiah@lancaster.ac.uk 


\begin{abstract}
${ }^{1}$ Alpa Shah, Ethnography? 2017, Hau: Journal of Ethnographic Theory 7 (1): 45-59
${ }^{2}$ Since writing this article an excellent collection of work around bringing the fields of anthropology and theology within the context of African Christianity has been published, which addresses several points made in this article. For more details read, Lauterbach, Karen, and Mika Vähäkangas, eds. Faith in African Lived Christianity: Bridging Anthropological and
\end{abstract} Theological Perspectives. Leiden: Boston: Brill, 2020.

${ }^{3}$ Ibid., pp3-5

${ }^{4}$ Charlotte A. Davies, Reflexive Ethnography, London: Routledge, 1999, pp67-76 and Harry

F. Walcott, Writing up Qualitative Research, Thousand Oaks: SAGE Publications, 2001, p73

${ }^{5}$ Paul Atkinson, The Ethnographic Imagination: Textual Construction of Reality, London:

Routledge, 1990, pp129-155

${ }^{6}$ Harry F Walcott, Writing up Qualitative Research, pp8-10, 19

${ }^{7}$ Charlotte A. Davies, Reflexive Ethnography, p6

${ }^{8}$ Isabelle Baszanger and Nicolas Dodier, Ethnography: Relating the Part to the Whole in David Silverman, ed. Qualitative Research: Theory, Method and Practice, London: SAGE Publications, 1997, pp9,10, Clifford Geertz also argues for a similar understating in his book, Local Knowledge, New York: Basic Books, 2000, p59

${ }^{9}$ Jody Miller and Barry Glassner, The 'Inside' and the 'Outside': Finding Realities in Interviews in David Silverman, ed. Qualitative Research: Theory, Method and Practice, p111

${ }^{10}$ Johann M. Vento, Women and Religion, Blackwell Publishing Ltd 2012

${ }^{11}$ Clifford Geertz, Available Light, Princeton: Princeton University Press, 2000, p184

12 Jack David Eller, Introducing Anthropology of Religion, London: Routledge, 2007, p28

${ }^{13}$ Talal Asad, Genealogies of Religion, p47

${ }^{14}$ Tim Ingold, The Perception of the Environment, p168 
${ }^{15}$ Pierre Bourdieu, Logic of Practice, translated by Richard Nice, Cambridge: Polity Press, 1999, p55

${ }^{16}$ Stephen Priest, Merleau-Ponty, London: Routledge, 1998, p230

${ }^{17}$ Monika M. Langer, Merleau-Ponty's Phenomenology of Perception, London: Macmillan, 1989, p117

${ }^{18}$ Fieldwork was conducted in South India between 2007-2011 as part of doctoral research

${ }^{19}$ Some of the community members claim that Rani is mentally unstable, since she believes in the plausibility of her experiences.

${ }^{20}$ David Morgan, The Sacred Gaze, London: University of California Press, 2005, p75ff

${ }^{21}$ For a broad discussion on this subject see Elisabeth Arweck \& William J.F Keenan, ed.

Materializing Religion: Expression, Performance and Ritual, Aldershot: Ashgate 2006

${ }^{22}$ The Ghana Statistical Service, The government of Ghana census report 2019

${ }^{23}$ Paul Gifford, Ghana's New Christianity: Pentecostalism in a Globalising African Economy, C.Hurst Pub: London, 2004 and J. Kwabena Asamoah-Gyadu, Sighs and Signs of the Spirit: Ghanaian Perspectives on Pentecostalism and Renewal in Africa, Regnum: Oxford, 2015

${ }^{24}$ Anthropological fieldwork was conducted in Ghana between 2014-2018

${ }^{25}$ The study among the three mega churches in Accra, Ghana was part of a wider research project on Ghanaian Pentecostal Christianity.

${ }^{26}$ Lancaster University Knowledge Exchange funded project on Christian Muslim relations, 2014-2017

${ }^{27}$ Paul Bagguleya and Yasmin Hussain, Ethnic Riots in United Kingdom in 2001, in Stevan Ratuva ed., Palgrave Handbook of Ethnicity, Palgrave: London, 2019

${ }^{28}$ In England at a popular level people use christening to mean baptism as well and often used interchangeably

${ }^{29}$ Stephen Priest, Merleau-Ponty, London: Routledge, 1998, p230 and Monika M. Langer, Merleau-Ponty's Phenomenology of Perception, London: Macmillan, 1989, p1 17 
30 Joel Robbins, "World Christianity and the Reorganization of the Disciplines: On the Emerging Dialogue between Anthropology and Theology." In Theologically Engaged Anthropology, ed. J. D. Lemons, 226-43. Oxford: Oxford University Press. 2018

${ }^{31}$ Miyazaki, Hirokazu. The Method of Hope. Anthropology, Philosophy, and Fijian Knowledge. Palo Alto, CA: Stanford University Press, 2004.

${ }^{32}$ Boopalan, Sunder John. Saving the World Through Ethnography, Journal of World Christianity, Vol.10, No.1, 2020, p18

${ }^{33}$ Talal Asad, Genealogies of Religion, p52

${ }^{34}$ Devaka Premawardhana, In Praise of Ambiguity: Everyday Christianity through the Lens of Existential Anthropology, Journal of World Christianity, Vol.10, No.1, 2020, p46

\section{References}

Arweck, Elisabeth and Keenan, William J.F. ed. Materializing Religion: Expression, Performance and Ritual, Aldershot: Ashgate 2006

Asad, Talal. Genealogies of Religion, London: The Johns Hopkins University Press, 1993 Asamoah-Gyadu, J. Kwabena. Sighs and Signs of the Spirit: Ghanaian Perspectives on Pentecostalism and Renewal in Africa, Regnum: Oxford, 2015

Atkinson, Paul. The Ethnographic Imagination: Textual Construction of Reality, London:

Routledge, 1990

Bagguleya, Paul and Hussain, Yasmin. Ethnic Riots in United Kingdom in 2001, in Stevan Ratuva ed., Palgrave Handbook of Ethnicity, Palgrave: London, 2019

Baszanger, Isabelle and Dodier, Nicolas. Ethnography: Relating the Part to the Whole in David Silverman, ed. Qualitative Research: Theory, Method and Practice, London: SAGE Publications, 1997 
Bourdieu, Pierre. Logic of Practice, translated by Richard Nice, Cambridge: Polity Press, 1999

Davies, Charlotte A. Reflexive Ethnography, London: Routledge, 1999

Eller, Jack David. Introducing Anthropology of Religion, London: Routledge, 2007

Geertz, Clifford. Available Light, Princeton: Princeton University Press, 2000

Geertz, Clifford. Local Knowledge, New York: Basic Books, 2000

Gifford, Paul. Ghana's New Christianity: Pentecostalism in a Globalising African Economy,

C.Hurst Pub: London, 2004

Ingold, Tim. The Perception of the Environment, London: Routledge, 2000

Langer, Monika M. Merleau-Ponty’s Phenomenology of Perception, London: Macmillan, 1989

Lauterbach, Karen, and Vähäkangas, Mika. eds. Faith in African Lived Christianity: Bridging Anthropological and Theological Perspectives. Leiden: Boston: Brill, 2020.

Miller, Jody and Glassner, Barry. The 'Inside' and the 'Outside': Finding Realities in Interviews in David Silverman, ed. Qualitative Research: Theory, Method and Practice, London: SAGE Publications, 1997

Miyazaki, Hirokazu. The Method of Hope. Anthropology, Philosophy, and Fijian Knowledge. Palo Alto, CA: Stanford University Press, 2004.

Morgan, David. The Sacred Gaze, London: University of California Press, 2005

Poobalan, Sunder John. Saving the World Through Ethnography, Journal of World

Christianity, Vol.10, No.1, 2020

Premawardhana, Devaka. In Praise of Ambiguity: Everyday Christianity through the Lens of Existential Anthropology, Journal of World Christianity, Vol.10, No.1, 2020

Priest, Stephen. Merleau-Ponty, London: Routledge, 1998 
Robbins, Joel. "World Christianity and the Reorganization of the Disciplines: On the Emerging Dialogue between Anthropology and Theology.” In Theologically Engaged Anthropology, ed. J. D. Lemons, Oxford: Oxford University Press. 2018

Shah, Alpa, Ethnography?, Hau: Journal of Ethnographic Theory 7 (1), 2017

The Ghana Statistical Service, The government of Ghana census reports, 2019

Vento, Johann M. Women and Religion, Lodon: Blackwell Publishing Ltd, 2012

Walcott, Harry F. Writing up Qualitative Research, Thousand Oaks: SAGE Publications, 2001 